\title{
MINAT BACA SISWA KELAS V SD NEGERI HARJOWINANGUN 02 TERSONO BATANG
}

\author{
Yuniar Indri Hapsari ${ }^{1}$, lin Purnamasari ${ }^{2}$,Veriliyana Purnamasari ${ }^{3}$ \\ 1,2,3 Program Studi PGSD Universitas PGRI Semarang \\ e-mail: Yuniarhapsari15@gmail.com ${ }^{1}$, purnamasari123@gmail.com², Veriliyana34@gmail.com³
}

\begin{abstract}
ABSTRAK
Artikel ini bertujuan untuk mengetahui faktor yang mempengaruhi minat baca dan tingkat minat baca siswa kelas V SD Negeri Harjowinangun 02 tahun 2018/2019. Jenis penelitian ini adalah penelitian kualitatif dengan pendekatan deskriptif. Obyek penelitian yaitu siswa kelas V SD Negeri Harjowinangun 02 Tersono yang berjumlah 15 siswa. Instrumen penelitian yang digunakan berupa lembar observasi, pedoman wawancara, lembar angket, dan dokumentasi. Hasil analisis berdasarkan observasi, wawancara, dan, angket dapat diperoleh bahwa minat baca siswa kelas V SD Negeri Harjowinangun 02 rendah. Faktor yang mempengaruhi yaitu faktor internal dan eksternal. Faktor internal berupa kecerdasan, minat dan perhatian, motivasi, ketekunan, sikap, kebiasaan membaca, serta kondisi fisik dan kesehatan. Minat baca siswa tidak akan muncul jika tidak terdapat kemauan, kesehatan, kondisi fisik, kecerdasan, dan motivasi dari dalam siswa. Perpustakaan yang seadanya, bahan bacaan yang sudah usang bahkan beberapa tidak layak pakai, rendahnya dorongan dari guru, tidak dorongan dari orang tua, orang tua yang tidak memfasilitasi dikarenakan ekonomi kurang, tidak ada perhatian orang tua terhadap minat membaca anak. kebanyakan orang tua lebih terfokus pada hasil belajar, pembiasaan membaca yang tidak didapatkan siswa sejak kecil. Pengaruh lingkungan dan teman bermain yang tidak terbiasa dengan membaca secara tidak langsung akan mempengaruhi minat baca siswa. Pengaruh teknologi yang tidak terkendali. Misalnya pengaruh smartphone atau gadget tidak digunakan dengan bijak, pengaruh acara televisi sehingga siswa melupakan tugasnya sebagai siswa.
\end{abstract}

Kata Kunci : Minat Baca, Siswa Sekolah Dasar

\begin{abstract}
This article aimed to determine the factors that influence reading interest and the level of reading interest of fifth grade students of Harjowinangun State Elementary School 02 2018/2019. This research was a qualitative research with descriptive approach. The object of the research was the fifth grade students of Harjowinangun 02 Tersono Elementary School with 15 students. The research instruments were observation sheets, interview guidelines, questionnaire sheets, and documentation. The results of the analysis based on observations, interviews, and questionnaires can be obtained that the reading interest of fifth grade students at SD Negeri Harjowinangun 02 is low. The influencing factors are internal and external factors. Internal factors such as intelligence, interest and attention, motivation, perseverance, attitude, reading habits, and physical and health conditions. Students' interest in reading will not arise if there is no will, health, physical condition, intelligence, and motivation from within students. Poor library, outdated reading materials and even some are not suitable for use, low encouragement from teachers, no encouragement from parents, parents who do not facilitate due to lack of economy, there is no parent's attention to children's reading interest. Most parents are more focused on learning outcomes, a habit of reading that students don't get since they were young. The influence of the environment and playmates who are not accustomed to reading indirectly will affect students' reading interest. The influence of uncontrolled technology. For example the influence of a smartphone or gadget is not used wisely, the influence of television shows so students forget their assignments as students.
\end{abstract}

Keywords : Reading interest, Elementary School Students 


\section{Pendahuluan}

Membaca dapat membuka dan memperluas pengetahuan seseorang. Semakin banyak membaca semakin dalam pengetahuan yang diperoleh. Membaca merupakan kegiatan mengambil makna dari suatu bacaan dengan tujuan mengembangkan pengetahuan dan potensi seseorang. Dalam membaca individu membutuhkan kemampuan mengintegrasikan, mencermati serta memahami inti dari apa yang dibaca. Sudut pandang atau mind set setiap individu dapat berubah melalui membaca. Individu mengarahkan pandangan keluar. Bacaan membuka mata dan pikiran sehingga seseorang tidak terikat pada apa yang ia lihat disekelilingnya saja tetapi sampai ke penjuru dunia.

Menurut peraturan Undang-Undang Republik Indonesia Nomor 43 Tahun 2007 tentang Perpustakaan bahwa budaya kegemaran membaca dilakukan melalui keluarga, satuan pendidikan, dan masyarakat dengan kerjasama antara pemerintah dalam upaya peningkatan minat baca, dimana pemerintah bertindak sebagai penanggungjawab utama dan pustakawan melakukan kinerja yang optimal (www.perpusnas.go.id).

Seperti yang dituturkan oleh David Shenk "Buku atau membaca adalah kebalikan dari menonton/televisi. (Buku memang lambat, namun menarik hati, menginspirasi, mengasah otak, dan menumbuhkan kreativitas).

Namun kenyataanya hiburan menjadi pilihan yang paling disukai dari pada membaca. Menonton televisi adalah salah satu hiburan yang sangat diminati masyarakat Indonesia. Walaupun televisi mengandung banyak informasi tentang pengetahuan akan tetapi tidak semua pengetahuan mampu dipahami dari televisi. Misalkan saja filsafat tidak bisa dipelajari dari televesi atau radio maka harus belajar dari buku.

Masyarakat lebih senang menonton TV daripada membaca buku. Menurut ungkapan Titik Kismiati Kepala Pusat Statistik tahun 2012, sebanyak 91,58\% penduduk Indonesia yang berusia 10 tahun keatas lebih suka menonton televisi. Hanya sekitar 17,58 persen saja penduduk yang gemar membaca buku, surat kabar, atau majalah. Seseorang yang sering membaca mempunyai perbandingan yang sangat berbeda dengan seseorang yang tidak pernah membaca. Melalui membaca seseorang lebih terbuka cakrawala selain itu seseorang mempunyai kesempatan melakukan refleksi dan meditasi, sehingga budaya baca lebih terarah pada budaya intelektual dari pada budaya hiburan yang sempit.

Sebuah studi yang dilakukan Central Connecticut State University pada tahun 2016 mengenai "Most Literate Nations in The World" menyebutkan bahwa Indonesia menempati urutan ke-60 dari total 61 negara, atau dengan kata yang lain minat baca masyarakat Indonesia disebut-sebut hanya sebesar 0,01 persen atau satu berbanding sepuluh ribu. Generasi muda masa kini lebih mementingkan apa yang mereka sukai daripada apa yang bermanfaat untuk mereka. Terutama sesuatu yang instan dan tidak mengeluarkan biaya banyak pasti sangat disenangi para generasi muda. Salah satu contohnya yaitu penggunaan gadget untuk mengakses internet. Generasi muda zaman modern ini menggunakan gadget hanya untuk kegiatan yang berbau kekinian. Data yang dihimpun statista.com pada januari 2018 disebutkan bahwa 44 persen populasi masyarakat Indonesia mengambil foto dan video menggunakan ponsel mereka. Menggali informasi melalui gadget merupakan hal yang kesekian kali. Sehingga akibatnya kaum yang mayoritas merupakan remaja itu kehilangan minat baca.

Kegiatan menyerap pengetahuan dari buku terganti oleh kegiatan mengotak-atik gadget. Di tingkat pendidikan dasar, kebiasaan membaca anak-anak masih rendah berdasarkan pendapat Putra dalam Triatma (2016:168). Fakta itu diperkuat dengan hasil penilaian tiga tahunan pada akhir 2016 oleh Organisasi untuk Kerja Sama Ekonomi dan Pembangunan (OECD) tentang budaya literasi 72 negara melalui Program for International Students Assesment bahwa indeks literasi sains dan matematika siswa Indonesia naik cukup bermakna masing-masing 21 dan 11 poin: 382 poin pada 2012 menjadi 403 tahun 2015, serta 375 tahun 202 dan 386 pada 2015. Sedangkan indeks literasi membaca hanya naik satu poin 369 pada 2012 dan 397 pada 2015.

Menurut Dalman (2013:7) membaca adalah proses perubahan bentuk lambang/tanda /tulisan menjadi wujud bunyi yang bermakna. Berdasarkan pendapat Dalman membaca 
merupakan proses seseorang dalam merubah bentuk lambang atau tanda atau tulisan menjadi bunyi. Seseorang yang mampu membaca berarti mengenal lambang atau tanda atau tulisan terlebih dahulu kemudian diucapkan. Setiap yang dibaca pasti mempunyai arti untuk mendapatkan informasi yang diinginkan.

Tarigan dalam Achmad (2016:42) menyebutkan bahwa membaca suatu proses yang dilakukan serta dipergunakan oleh pembaca untuk memperoleh pesan yang hendak disampaikan oleh penulis melalui media kata-kata atau bahasa tulis. Membaca merupakan proses kegiatan yang dilakukan oleh pembaca dalam mencari informasi atau pesan yang terkandung dalam susatu bacaan atau media kata-kata atau bahasa tulis. Dengan banyak membaca maka pengetahuan yang diperoleh semakin banyak.

Menurut Lado dalam Achmad (2016: 42) membaca adalah memahami pola-pola bahasa dari gambaran tertulisnya. Kegiatan memahami bentuk atau pola bahasa dari pesan atau gambaran tertulis. Pola-pola bahasa merupakan struktur bahasa yang menjadi satu sehingga terbentuk suatu bacaan. Struktur bahasa tersebut antara lain, lambang, simbol, kata, kalimat, dan tanda.

Berdasarkan pendapat tersebut dapat disimpulkan bahwa membca merupakan kegiatan seseorang dalam mengambil informasi atau pesan yang terdpat pada suatu bacaan. Membaca merupakan bentuk pelafalan dari suatu lambang, simbol, atau pola sehingga dapat diambil makna dari bentuk atau pola tersebut. Segala bentuk bahan bacaan yang baik akan memberikan pengetahuan bagi pembaca.

Rahim dalam Triatma (2016:168) menyebutkan bahwa orang yang mempunyai minat baca yang kuat akan diwujudkannya dalam kesediaannya untuk mendapat bahan bacaan dan kemudian membacanya atas kesadarannya sendiri. Bahan bacaan yang dibaca meliputi surat kabar, majalah, buku pelajaran, buku pengetahuan di luar buku pelajaran, dan buku cerita.

Menurut Word Economic Forum (2016) menyebutkan bahwa, literasi merupakan dasar (bagaimana peserta didik menerapkan keterampilan berliterasi untuk kehidupan sehari-hari), kompetensi (bagaimana peserta didik menyikapi tantangan yang kompleks), dan karakter (bagaimana peserta didik menyikapi perubahan lingkungan mereka). Tidak mudah untuk mendorong siswa agar kemauan membacanya meningkat. Siswa harus menumbuhkan kesadaran dalam dirinya. Sedikit sekali siswa yang mempunyai kesadaran membaca. Kemajuan teknologi merubah hampir semua aspek menjadi digital salah satunya yaitu tingkat minat baca buku pada siswa. Siswa lebih tertarik pada sesuatu yang berbau digital seperti mengakses internet untuk hal yang menurutnya menyenangkan. Mengakses bacaan atau informasi merupakan hal yang kesekian kali. Penggunaan gadget yang tidak bijaksana berakibat negatif pada siswa. Bermain game online, berselancar di media sosial dan mengakses sesuatu yang mungkin tidak sesuai dengan moral akan membuang waktu mereka untuk belajar.

Gerakan Literasi berjalan sejak diterbitkanya Peraturan Menteri Pendidikan dan Kebudayaan Nomor 23 Tahun 2015 tentang Penumbuhan Budi Pekerti. Salah satu hal pokok yang tertuang dalam peraturan tersebut yaitu kewajiban membaca buku nonteks pelajaran selama 15 menit sebelum jam pembelajaran dimulai setiap hari di sekolah. Berdasarkan amanat tersebut, Direktorat Jenderal Pendidikan Dasar dan Menengah (Ditjen Dikdasmen) meluncurkan program Gerakan Literasi Sekolah (GLS). Untuk mengawali program Gerakan Literasi Sekolah Direktorat Jenderal Pendidikan Dasar dan Menengah pada awal tahun 2016 membentuk Satuan Tugas Gerakan Literasi Sekolah.

SD Negeri Harjowinangun 02 sudah menerapkan gerakan literasi sejak April tahun 2018. Literasi merupakan gerakan memahami, menganalisis dan menyerap informasi dari kegiatan menulis, membaca atau mendengarkan. Literasi diterapkan sejalan dengan diterapkanya kurikulum 2013.

Gerakan literasi belum dapat dimaksimalkan oleh siswa, guru ataupun kepala sekolah. Berdasarkan buku kunjungan perpustakaan SD Negeri Harjowinangun 02, menunjukkan 2 atau 3 orang siswa yang mengunjungi perpustakaan setiap minggunya. Pada saat waktu luang siswa lebih memilih bercerita, bermain dan membeli jajanan dibandingkan membaca buku diperpustakaan. Sarana prasarana yang kurang mendukung menyebabkan siswa 
malas untuk membaca. Perpustakaan sekedarnya, buku-buku yang masih minim, tidak menarik lagi untuk dibaca dan usang. Pengaruh gadget dalam minat baca anak sangatlah beragam diantaranya adalah anak akan malas membaca buku karena lebih tertarik pada media sosial atau permainan, menyita kegiatan literasi anak, anak mempunyai anggapan mencari informasi di buku tidak lebih penting dari pada Gadget.

\section{Metode}

Metode penelitian yang digunakan yaitu kualitatif dengan pendekatan deskriptif . Pendekatan deskriptif dilakukan dengan cara menggambarkan atau menjelaskan fakta-fakta atau data-data yang diperoleh dari sumber data. Data-data yang sudah diperoleh kemudian dianalisis dan diuraikan untuk menemukan faktor-faktor mempengaruhi minat dan tingkat minat baca siswa kelas V SD Negeri Harjowinangun 02 tahun pelajaran 2018/2019. Penelitian telah dilakukan di SD Negeri Harjowinangun 02 Tersono Batang. Penelitian dilakukan selama dua bulan yaitu pada bulan April 2019 sampai Mei 2019. Sumber data yang digunakan peneliti untuk mendapatkan informasi tentang minat baca siswa kelas V SD N Harjowinangun 02 Tahun Ajaran 2018/2019 adalah kata-kata dan tindakan,sumber tertulis,foto,dan data statistik. Kata-kata dan tindakan diambil dari hasil wawancara pada informan. Informan tersebut adalah kepala sekolah, wali kelas, orang tua siswa, dan siswa.

\section{Hasil dan Pembahasan}

Penelitian diawali dengan melakukan observasi menunjukkan bahwa minat baca siswa kelas V SD Negeri Harjowinangun 02 sangat rendah. Rendahnya minat baca tersebut sesuai dengan buku kunjunngan perustakaan. Buku kunjungan perpustakaan menunjukkan bahwa sangat sedikit sekali siswa yang mengunjungi perpustakaan. Pihak sekolah padahal sudah menjalankan Gerakan Literasi Sekolah atau disebut juga dengan GLS. Gerakan Literasi Sekolah diharapkan mampu meningkatkan minat baca siswa yang rendah, karena dalam GLS terdapat pembiasaan membaca buku non teks selama 15 menit sebelum pembelajaran dimulai.

Kegiatan membaca tidak dapat berjalan dengan berkesinambungan jika tidak ada pihak terkait. Pihak-pihak tesebut diantaranya adalah pemerintah, sekolah, dan orang tua. Dalam observasi yang peneliti lakukan bahwasanya pihak pemerintah terutama Desa tidak memberi kontribusi pada minat baca siswa. Belum ada fasilitas yang mendukung untuk meningkatkan minat baca siswa.

Sekolah merupakan lembaga pertama yang seharusnya mempehatikan minat baca siswa. Fasilitas yang seharusnya mewadahi akan tetapi pada kenyataanya SD Negeri Harjowinangun 02 belum terpenuhi. Fasilitas yang belum memadahi perihal minat baca siswa dikarenakan tidak adanya biaya untuk memperbaiki fasilitas.

Sekolah didalamnya terdapat juga guru, kepala sekolah dan pihak terkait lainya. Minat membaca siswa baik jika guru merupakan contoh yang baik dalam membaca di sekolah. Pada faktanya guru sendiri belum menjadi contoh yang baik dalam kegiatan membaca bagi siswa. Guru hanya memberikan apa yang pokok saja seperti materi pelajaran. Guru ingin siswanya mempunyai tingkat minat baca tinggi akan tetapi dalam membangun motivasi dan memberi fasilitas membaca bagi siswa masih kurang terpenuhi.

Tidak semua siswa benar-benar membaca buku, banyak siswa yang membaca buku hanya sekedar membolak-balikan lembaran bacaan.

Siswa membaca jika benar-benar butuh. Misalnya mendapat tugas dari guru secara sengaja siswa akan mencari jawaban dalam bacaan. Perlu pemahaman dan perlakuan dengan menyesuaikan karakteristik siswa agar minat baca siswa meningkat. Hanya dengan menyuruh siswa membaca itu tidak cukup.

\section{Faktor Temuan Hasil Penelitian}

Banyak faktor yang menyebabkan rendahnya minat baca siswa kelas V SD Negeri Harjowinangun 02 diantaranya faktor internal dan faktor eksternal. Faktor internal merupakan 
faktor yang berasal dari dalam siswa sendiri. Faktor eksternal meliputi lingkungan sekolah, lingkungan keluarga.

\section{a. Faktor Internal}

Faktor internal faktor yang timbul dari diri siswa sendiri diantaranya yaitu kecerdasan, minat dan perhatian, motivasi, ketekunan, sikap, kebiasaan membaca, serta kondisi fisik dan kesehatan. Minat baca siswa tidak akan muncul jika tidak terdapat kemauan, kesehatan, kondisi fisik, kecerdasan, dan motivasi dari dalam siswa. Siswa beranggapan bahwa membaca meupakan kegiatan yang tidak menarik.

Siswa yang tingkat kecerdasanya rendah akan sulit untuk membaca sehingga berpengaruh terhadap kemauan membacanya. Kesehatan sangat penting diperlukan siswa untuk melakukan suatu kegiatan. Jika terdapat gangguan kesehatan pada siswa maka sulit siswa akan membaca atau beraktivitas lain. Kondisi fisik siswa juga berpengaruh terhadap minat baca siswa. Siswa yang terganggu kondisi fisiknya misalnya siswa tuna netra akan sulit membaca dengan huruf biasa.

\section{b. Faktor Eksternal}

Faktor eksternal merupakan faktor yang berasal dari luar siswa. Perpustakaan yang seadanya, bahan bacaan yang sudah usang bahkan beberapa tidak layak pakai, rendahnya dorongan dari guru, tidak dorongan dari orang tua, orang tua yang tidak memfasilitasi dikarenakan ekonomi kurang, tidak ada perhatian orang tua terhadap minat membaca anak. kebanyakan orang tua lebih terfokus pada hasil belajar, pembiasaan membaca yang tidak didapatkan siswa sejak kecil. Pengaruh lingkungan dan teman bermain yang tidak terbiasa dengan membaca secara tidak langsung akan mempengaruhi minat baca siswa. Pengaruh teknologi yang tidak terkendali. Misalnya pengaruh smartphone atau gadget tidak digunakan dengan bijak, pengaruh acara televisi sehingga siswa melupakan tugasnya sebagai siswa. Bermain bersama teman tidak mengenal waktu.

Berdasarkan analisis angket minat baca siswa dapat direkapitulasi berdasar indikator angket kemudian skor setiap individu diakumulasikan. Indikator 1 terdiri dari dua pernyataan, indikator 2 terdiri dari empat pernyataan, indikator 3 terdiri dari dua pernyataan, indikator 4 terdiri dari dua pernyataan, indikator 5 terdiri dari enam pernyataan, dan indikator 6 teridiri dari satu pernyataan. Dari indikator tersebut dapat dihasilkan tabel rekapitulasi angket minat baca siswa kelas $v$ sebagai berikut :

Tabel 1. Rekapitulasi Angket Siswa

\begin{tabular}{lllllllll}
\hline No & Nama Siswa & \multicolumn{9}{l}{ Indikator } & \multicolumn{7}{l}{ Jumlah } \\
\cline { 3 - 6 } & & 1 & 2 & 3 & 4 & 5 & 6 & \\
1. & Elga Dharmawan & 5 & 12 & 7 & 5 & 15 & 3 & 42 \\
2. & Fernanda Hilda P & 5 & 13 & 6 & 5 & 17 & 3 & 49 \\
3. & Hanafi Ahmad & 8 & 9 & 8 & 8 & 17 & 3 & 53 \\
4. & Indah Lestari & 8 & 10 & 8 & 8 & 21 & 4 & 59 \\
5. & Lintang Kukuh W & 6 & 13 & 6 & 4 & 14 & 2 & 47 \\
6. & M Abrar R & 7 & 12 & 7 & 5 & 14 & 2 & 47 \\
7. & Nauvatun Naswa S & 6 & 11 & 6 & 3 & 13 & 2 & 41 \\
8. & Seila Yulia K & 7 & 14 & 7 & 7 & 20 & 4 & 59 \\
9. & Alif Budi P & 7 & 13 & 7 & 6 & 15 & 2 & 50 \\
10. & Bertha Felicia S & 4 & 12 & 6 & 6 & 16 & 2 & 46 \\
11. & Galih Linggar J & 6 & 12 & 6 & 3 & 13 & 1 & 41 \\
12. & Syifa Vivi Syifani & 7 & 9 & 6 & 5 & 15 & 2 & 44 \\
13. & Steven Stya Budi & 5 & 10 & 6 & 4 & 13 & 2 & 40 \\
14. & Dikdo Adi H & 7 & 14 & 7 & 5 & 19 & 3 & 55 \\
15. & Wika Filda P & 6 & 11 & 6 & 3 & 14 & 2 & 42 \\
\hline
\end{tabular}


Keterangan :

Skor maksimal $=$ (skor maksimal indikator $1+$ skor maksimal indikator $2+$ skor maksimal indikator 3 + skor maksimal indikator 4 + skor maksimal indikator 5 + skor maksimal indikator 6)

$\begin{aligned} \text { Skor maksimal } & =(8+16+8+8+24+8) \\ & =72\end{aligned}$

Rentang skor

$1-18$ : Sangat rendah

$19-36$ : Rendah

$37-54$ : Rata-rata

$55-72$ : Tinggi

Berdasarkan tabel hasil rekapitulasi angket siswa dapat disimpulkan bahwa minat baca siswa kelas v SD Negeri Harjowinangun 02 Kecamatan Tersono Kabupaten Batang memiliki minat baca sedang atau pada tingkatan rata-rata. Kemudian peneliti menyajikan data tersebut dalam bentuk diagram sebagai berikut:

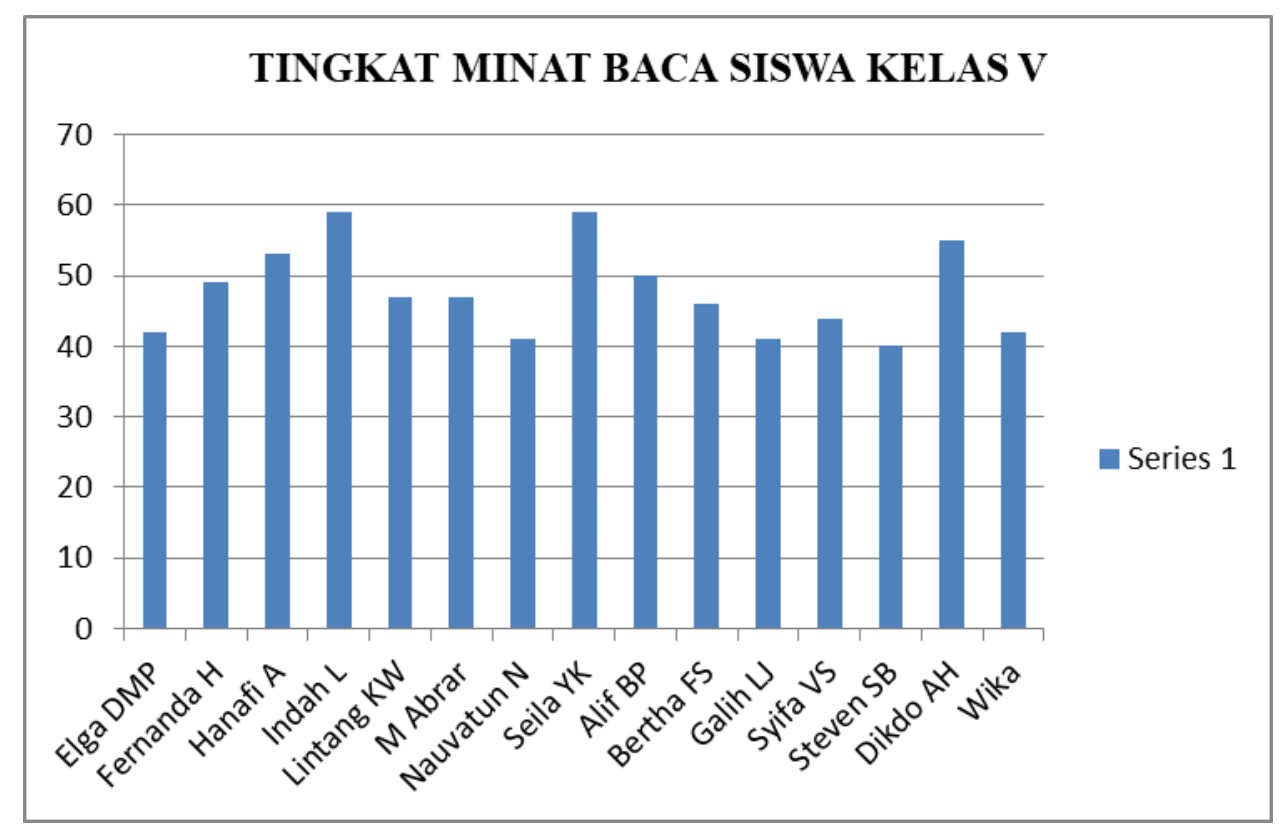

Gambar 1. Diagram Tingkat Minat Baca Siswa Kelas V

Hasil analisis wawancara dengan kepala sekolah dapat diuraikan bahwa minat baca yang dimiliki siswa kelas $v$ rendah. Rendahnya minat baca siswa dapat dilihat dari perilaku siswa sehari-hari antara lain yaitu tidak adanya siswa yang mengunjungi perpustakaan setiap harinya, masih banyak siswa yang tidak membaca saat kegiatan membaca selama 15 menit sebelum pembalajaran berlangsung, saat istirahat siswa lebih suka bermain dengan teman atau membeli jajanan. Faktor yang mempengaruhi rendahnya minat baca siswa adalah tidak tersedianya bahan bacaan yang menarik, perpustakaan yang seadanya, lebih suka bermain game online atau gadget.

Hasil analisis wawancara dengan wali kelas v SD Negeri Harjowinangun 02 bahwasanya minat baca siswa yang rendah, siswa hanya mau membaca ketika digandakan dongeng atau cerita yang menarik, siswa lebih menyukai playstation, game online atau gadget, tidak ada dorongan dan dukungan dari orang tua siswa. Membentuk siswa yang mempunyai tingkat baca tinggi sekarang sangat sulit. Siswa lebih senang melakukan apa yang siswa sukai. Terlebih lagi sejak kecil siswa tidak mempunyai kebiasaan membaca. Jadi 
untuk membiasakan atau merubah kebiasaan siswa dari tidak mempunyai minat baca ke siswa yang mempunyai minat baca sangatlah tidak mudah.

\section{Simpulan dan Saran}

Berdasarkan hasil penelitian yang dilakukan peneliti dapat disimpulkan bahwa minat baca siswa kelas $v$ ada pada tingkat rata-rata menengah ke bawah. Hal ini dibuktikan berdasarkan hasil wawancara dengan kepala sekolah dan wali kelas v SD Negeri Harjowinangun 02 beserta rekapitulasi angket yaitu 12 dari 15 siswa kelas V SD Negeri Harjowinangun 02 yang mengisi angket dengan hasil rentang skor antara 37 - 54 atau lebih dari 37 dan kurang dari 50 . Faktor yang menjadikan minat siswa pada tingkat rata-rata ke bawah yaitu faktor intern dan ekstern.

Faktor intern merupakan faktor yang berasal dari diri sendiri seperti kecerdasan, minat dan perhatian, motivasi, ketekunan, sikap, kebiasaan membaca, serta kondisi fisik dan kesehatan. Sedangkan faktor ekstern merupakan faktor yang berasal dari luar individu tersebut seperti Perpustakaan yang seadanya, bahan bacaan yang sudah usang bahkan beberapa tidak layak pakai, rendahnya dorongan dari guru, tidak dorongan dari orang tua, orang tua yang tidak memfasilitasi dikarenakan ekonomi kurang, tidak ada perhatian orang tua terhadap minat membaca anak. kebanyakan orang tua lebih terfokus pada hasil belajar, pembiasaan membaca yang tidak didapatkan siswa sejak kecil. Pengaruh lingkungan dan teman bermain yang tidak terbiasa dengan membaca secara tidak langsung akan mempengaruhi minat baca siswa. Pengaruh teknologi yang tidak terkendali. Misalnya pengaruh smartphone atau gadget tidak digunakan dengan bijak, pengaruh acara televisi sehingga siswa melupakan tugasnya sebagai siswa. Bermain bersama teman tidak mengenal waktu, sehingga tidak ada waktu untuk belajar apalaggi membaca.

\section{Daftar Pustaka}

Achmad, Alek.(2016). Bahasa Indonesia Untuk Perguruan Tinggi. Jakarta: Erlangga.

Dalman. (2017). Keterampilan Membaca. Jakarta: Pt Raja Grafindo Persada.

Danim Sudarwan.(2014). Perkembangan Peserta Didik. Bandung: Alfabeta.

Elferida, K., \& Rahmah, E. (2012). Peran Pustakawan Dalam Memotivasi Siswa Memanfaatkan Perpustakaan Smk Tamansiswa Padang. IImu Informasi Perpustakaan Dan Kearsipan, 1(1), 436-441.

Handayaningrum, Y. (2010). Penerapan Media Cerita Bergambar (Cergam) Untuk Meningkatkan Minat Baca Biologi Siswa Pada Pokok Bahasan Bahan Kimia Dalam Makanan Kelas Viii Smp Negeri 7 Surakarta Tahun Pelajaran 2008/2009 (Doctoral Dissertation, Universitas Sebelas Maret).

Hardika Yulinar A - E-Jurnal Skripsi Mahasiswa Pgsd.2018. Gerakan Literasi Sekolah (Gls) Sebagai Optimalisasi Minat Baca Siswa Sekolah Dasar Kecamatan Wonosalam Kabupaten Demak. Universitas Pgri Semarang. Diakses 01 Oktober 2018 (12:40 Wib)

Hari S - E-Jurnal Skripsi.2008. Membangun Minat Baca Anak Usia Dini Melalui Penyediaan Buku Bergambar. Universitas Negeri Malang. Diakses 29 Oktober 2018 (21:18 Wib)

In Triatma - E-Jurnal Skripsi Mahasiswa Tp.2016. Minat Baca Pada Siswa Kelas Vi Sekolah Dasar Negeri Delegan 2 Prambanan Sleman Yogyakarta. Journal.Student.Uny.Ac.Id. Diakses 18 September 2018 (07:02 Wib)

Ismawati Esti Dan Faraz Umaya. (2016). Belajar Bahasa Di Kelas Awal.Ombak. 
Kurnia, U. (2015). Efektivitas Penggunaan Gambar Pada Brosur Dalam Model Pembelajaran Problem Based Learning Untuk Meningkatkan Hasil Belajar Fisika Kelas Xi Sman 5 Padang. Pillar Of Physics Education, 6(2).

Masri S Putra. (2008). Menumbuhkan Minat Baca Sejak Dini. Jakarta: Pt Indeks.

Moleong, Lexy J.(2017). Metodologi Penelitian Kualitatif. Bandung: Remaja Rosdakarya

Parmadani, T. S., \& Latifah, L. (2017). Pengaruh Minat Baca, Sumber Belajar Dan Lingkungan Teman Sebaya Terhadap Prestasi Belajar Ekonomi. Economic Education Analysis Journal, 5(2), 505.

Rosidi Ajip. (1983). Pembinaan Minat Baca Bahasa Dan Sastra Daerah. Bandung: Remaja Rosda Karya

Sari, N. P., \& Lukitaningsih, R. (2013). Penerapan Konseling Kelompok Realita Untuk Meningkatkan Minat Baca Siswa. Jurnal Bk Unesa, 1(1).

Slameto. (2013). Belajar Dan Faktor-Faktor Yang Mempengaruhinya. Jakarta: Pt Rineka Cipta

Sugiyono. (2011). Metode Penelitian Kuantitatif Kualitatif Dan R\&D. Bandung: Alfabeta

Zuve, F. O. (2017). Peningkatan Kemampuan Menulis Eksposisi Menggunakan Strategi Pembelajaran Kooperatif Group Investigation. Jurnal Pendidikan Rokania, 1(2), 68-79. 